\title{
Mikroelem-terhelés hatása a tritikále termésére és elemfelvételére karbonátos csernozjom talajon
}

\author{
KÁDÁR IMRE és KASTORI RUDOLF
}

\begin{abstract}
MTA Talajtani és Agrokémiai Kutatóintézet (MTA TAKI), Budapest és Újvidéki Egyetem Mezőgazdasági Kara Szántóföldi és Zöldségnövények Kutatóintézete, Újvidék
\end{abstract}

\section{Bevezetés, irodalmi áttekintés}

A tritikále (XTriticosecale Witm.) a búza és a rozs keresztezéséből származó állandósult köztes búza-rozs hibrid, egy viszonylag új kalászos növényfaj. Jelentősége világviszonylatban növekszik, vetésterülete hazánkban megközelítette a 100 ezer ha-t. Egyaránt értékes takarmány- és kenyérgabona. Beltartalmi értékét emeli a mag jelentős fehérjekészlete, mely az évjárattól és a trágyázástól függően széles sávban ingadozhat. VOHRA és munkatársai (1991) szerint Kaliforniában a tyúktápok 60\% kukorica- és 30\% szójalisztet tartalmaznak akkor is, amikor az alapanyagot nem helyben termelik, hanem Közép-Nyugatról importálják. A szerző etetési kísérletei és számításai alapján a tritikále mind gazdasági, mind takarmányozási szempontból előnyös alternatívát jelenthet, mert tápanyagokban gazdag, csökkentheti nemcsak a kukorica-, hanem a szójalisztszükségletet is.

Magyarországon a tritikále gyakorlatilag mindenütt megterem és kiváló takarmányt adhat. Elterjedésével a jobb talajon termett kukorica vagy búza nagyobb része exportálható, valamint a fehérjeforrásul szolgáló szójaliszt importja mérsékelhetö. Korábbi vizsgálataink szerint savanyú homoktalajon a magtermés 1,4-2,5\% nitrogént, azaz 9-16\% nyersfehérjét tartalmazott az évektől, döntően azonban a trágyázástól függően (KÁDÁR \& SzEMES, 1994; KÁDÁR et al., 1999). Hasonló eredményekröl számol be Duna-Tisza közi meszes homokon beállított trágyázási kísérletében LÁsZTITY (1986).

Korábban LÁszTiTY (1984) összehasonlította a rozs és a tritikále szemtermésének ásványi összetételét egy NPK mütrágyázási kísérletben és megállapította, hogy a két növény makro- és mikroelem-készlete érdemben nem tér el egymástól. A trágyázatlan kontroll-, ill. NPK-trágyazott kezelésekben a tritikále termése 1,4, ill. 3,8 t/ha; míg ugyanitt a rozs 2,4 és 3,8 t/ha magtömeget adott. LÁszTITY (19871988), valamint LÁsZTITY és BICZÓK (1977-1988) részletesen vizsgálták a növény szárazanyagának gyarapodását és tápelemtartalmának változását a tenyészidő folyamán, valamint az NPK-kezelések függvényében meszes homoktalajon.

Postai cím: KÁDÁR IMRE, MTA Talajtani és Agrokémiai Kutatóintézet, 1022 Budapest, Herman Ottó út 15.E-mail: kadar@rissac.hu 
Ami az $1 \mathrm{t}$ magtermés és a hozzá tartozó melléktermés fajlagos elemtartalmát illeti LÁSZTITY és BICZÓK (1987-1988) az alábbi értékeket közli, mint kísérleti átlagokat: $30 \mathrm{~kg} \mathrm{~N}, 11 \mathrm{~kg} \mathrm{P} \mathrm{O}_{5}, 24 \mathrm{~kg} \mathrm{~K}{ }_{2} \mathrm{O}, 4 \mathrm{~kg} \mathrm{Ca}, 2 \mathrm{~kg} \mathrm{Mg}, 300 \mathrm{~g} \mathrm{Fe}, 98 \mathrm{~g} \mathrm{Mn}, 35 \mathrm{~g}$ $\mathrm{Zn}$ és $10 \mathrm{~g} \mathrm{Cu}$. A legnagyobb szórásokat a N-készlet mutatta, mely a kontrollkezelésen $24 \mathrm{~kg} / \mathrm{t}$, az NPK-trágyázotton $32 \mathrm{~kg} / \mathrm{t}$ értéket ért el a meszes homokon. Savanyú homoktalajon beállított nyírlugosi tartamkísérletünkben a kedvező 1991. évben 25-30 kg N, 10-12 kg $\mathrm{P}_{2} \mathrm{O}_{5}, 18-24 \mathrm{~kg} \mathrm{~K}_{2} \mathrm{O}, 2-3 \mathrm{~kg} \mathrm{Ca}, 2 \mathrm{~kg} \mathrm{Mg}, 70-140 \mathrm{~g} \mathrm{Fe}$, 200-600 g Mn, 45-80 g Zn és 7-11 g/t Cu fajlagos elemtartalmakat regisztráltunk (KÁDÁr \& SZEMES, 1994).

A fenti adatokat összevetve látható, hogy míg a fajlagos N-, P-, K- és $\mathrm{Cu}-$ tartalmak átlagai közelállók a két eltérő termőhelyen, addig a meszes talajon emelkedett $\mathrm{Ca}$ és Fe, ill. csökkent Mn és Zn értékek jellemzők. A fajlagos mikroelemtartalmakat közvetlenül nem használjuk trágyaigény becslésére a szaktanácsadás során, hiszen a mikroelemek felvehetőségét általában nem a talajbani mennyiségük, hanem egyéb talajtulajdonságok szabályozzák. A fontosabb makroelemek fajlagosai - elsősorban a N, P és K - viszont iránymutatóul szolgálhatnak.

Kérdés, vajon a tritikále hogyan reagál a talajszennyezésre? Milyen szennyező elemeket akkumulálhat szerveiben? Alkalmas lehet-e fitoremediációs célokra? Milyen mértékben vándorolhat a $\mathrm{Zn}$, Se és Mo mikroelem az utódnövény föld feletti hajtásába és hogyan befolyásolhatja a csíranövény növekedését? Ilyen és ehhez hasonló kérdésekre kerestük a választ kísérletünkben.

\section{Anyag és módszer}

Kísérletünket az MTA TAKI Nagyhörcsöki Kísérleti Telepén állítottuk be 1991 tavaszán. A termőhely löszön képződött karbonátos csernozjom talaja a szántott rétegben mintegy $5 \% \mathrm{CaCO}_{3}$-ot és 3\% humuszt tartalmaz. Fizikai féleségét tekintve vályog, 20\% agyag-, ill. 40\% leiszapolható rész frakcióval. Agyagásványainak közel felét illit, 1/3-át klorit, kisebb részét szmektit alkotja. SzŰCS (1965) részletes talajföldrajzi feltárása alapján a területet a dunavölgyi mészlepedékes csernozjomok közepes humuszrétegü változatába sorolja $50-100 \mathrm{~cm}$ humuszréteggel. A talajvíz tükre kb. $15 \mathrm{~m}$ mélyen helyezkedik el, szennyeződése felszíni kilúgzással gyakorlatilag kizárt. A telep éghajlata az Alföldéhez hasonlóan csapadékszegény és aszályra hajló.

A kísérlet terhelési szintjei 0, 90, 270 és $810 \mathrm{~kg} /$ ha mennyiséget jelentettek elemenként $\mathrm{AlCl}_{3}, \mathrm{As}_{2} \mathrm{O}_{3} / \mathrm{NaAsO}_{2}, \mathrm{BaCl}_{2}, \mathrm{CdSO}_{4}, \mathrm{~K}_{2} \mathrm{CrO}_{4}, \mathrm{CuSO}_{4}, \mathrm{HgCl}_{2}, \mathrm{NiSO}_{4}$, $\left(\mathrm{NH}_{4}\right)_{6} \mathrm{Mo}_{7} \mathrm{O}_{24}, \mathrm{~Pb}\left(\mathrm{NO}_{3}\right)_{2}, \mathrm{Na}_{2} \mathrm{SeO}_{3}, \mathrm{SrSO}_{4}$ és $\mathrm{ZnSO}_{4}$ sók formájában. Az extrém adagok a talajszennyezési szintek modellezését szolgálták. Az osztott parcellás elrendezésben a vizsgált 13 elem jelenti a föparcellát, míg a 4-4 terhelési szint (adag) az alparcellát $13 \times 4=52$ kezeléssel és 2 ismétléssel, azaz összesen 104 parcellával. A $21 \mathrm{~m}^{2}$ területủ parcellákat 1-1 m-es utak határolják hosszirányban a jobb megközelíthetőség és a talajáthordás megakadályozása érdekében. A parcellák teljes területe 2184, az utak és szegélyek területe 2008, a kísérlet bekerített összes területe $4192 \mathrm{~m}^{2}$. A növényi sorrend kukorica, sárgarépa, burgonya, borsó, cékla, 
spenót, búza, napraforgó, sóska, őszi árpa, repce és mák volt (KÁDÁR et al., 2000, 2003).

A kísérlet 13. évében Kitaro fajtájú tritikálét termesztettünk, amelyet 2002. október 1-jén gabona sortávolságra, 4-6 cm mélyre vetettünk, 55-60 db/fm csíraszámmal, ill. 200-220 kg/ha vetőmaggal. A tenyészidő során állománybonitálást végeztünk bokrosodás végén, virágzásban és aratáskor. Aratáskor növénymintavételre is sor került $8-8 \mathrm{fm}$, azaz $1-1 \mathrm{~m}^{2}$ föld feletti anyag begyüjtésével parcellán-

\section{1. táblázat}

A tritikále kísérletben végzett müveletek és megfigyelések 2003-ban (Mészlepedékes csernozjom talaj, Nagyhörcsök)

\begin{tabular}{|c|c|c|}
\hline $\begin{array}{l}\text { (1) } \\
\text { Müveletek és megfigyelések }\end{array}$ & Év, hó, nap & $\begin{array}{c}\text { (3) } \\
\text { Megjegyzés }\end{array}$ \\
\hline Öszi NPK műtrágyázás & 2002.09. 18. & Parcellánként kézzel \\
\hline Egyirányú szántás + gyürüshenger & 2002.09. 30 . & MTZ-80 + Lajta eke + gyürüshenger \\
\hline Kombinátorozás & 2002.09. 30 . & MTZ-50 + kombinátor \\
\hline Vetés + hengerezés & 2002. 10. 01 . & MTZ-50+ vetögép + gyürüshenger \\
\hline Tavaszi N mütrágyázás & 2003.03 .26 . & Parcellánként kézzel \\
\hline Állománybonitálás bokrosodásban & 2003.03 .26 . & Parcellánként 1-5 skálán \\
\hline Állománybonitálás virágzásban & 2003.05 .19$. & Parcellánként 1-5 skálán \\
\hline Állománybonitálás aratáskor & 2003.07 .03$. & Parcellánként 1-5 skálán \\
\hline Mintavétel aratáskor & 2003.07 .03$. & Parcellánként $8-8 \mathrm{fm}=1-1 \mathrm{~m}^{2}$ \\
\hline Kombájnolás & 2003.07.03. & Parcellánként $2,1 \times 6=12,6 \mathrm{~m}^{2}$ \\
\hline Mintakévék cséplése & 2003. 11. 24. & Parcellánként 8-8 fm \\
\hline Mintakévék őrlése analízisre & 2003. 11. 28. & Parcellánként 8-8 fm \\
\hline
\end{tabular}

ként a fö/melléktermék arányának megállapítására, valamint növényelemzés céljaira. A kísérletben végzett müveletekről és megfigyelésekről tételesen az 1. táblázat tájékoztat.

A szem- és a szalmamintákat ismétlésenként cc. $\mathrm{HNO}_{3}+$ cc. $\mathrm{H}_{2} \mathrm{O}_{2}$ elegyével roncsoltuk, majd ICP-technikával 23 elem meghatározására került sor. A Zn-, Moés Se-kezelések magmintáit a búza zsizsik (Sitophilus granarius) kártételére is vizsgáltuk ismétlésenként 40-40 g mag felhasználásával. A károsodott magvak mennyiségét az összes vizsgált mag \%-ában fejeztük ki. Ugyanezen kezelések minden ismétlésével csíráztatási vizsgálatokat is végeztünk. Meghatároztuk a csíranövények magasságát, a hajtás és a gyökér tömegét, valamint a hajtások elemösszetételét is. Ilyen módon a kezelések hatását próbáltuk meg nyomon követni az utódnövényen: hogyan módosulhat a csíranövény fejlödése, mennyiben vándorolnak a mag elemkészletei a föld feletti hajtásba?

Ami a csapadékellátottságot illeti, megemlítjük, hogy a mák elővetemény betakarítása és a tritikále vetése közötti időszakban $149 \mathrm{~mm}$ eső hullott. Ezt követően a tenyészidő 9 hónapja alatt mindössze $230 \mathrm{~mm}$ csapadékban részesült a terület. Elméletileg tehát a tritikále $379 \mathrm{~mm}$ csapadékkal rendelkezhetett, amennyiben a talaj a teljes csapadékmennyiséget befogadni és tárolni volt képes. A 2003. év első fele 
meglehetősen csapadékszegény volt: januárban 29, februárban 34, márciusban 5, áprilisban 22, májusban 30, júniusban $18 \mathrm{~mm}$ eső esett. Az előző évi eredményekről korábbi közleményünkben (KÁDÁR et al., 2003) számoltunk be.

\section{Kísérleti eredmények}

Bonitálásaink szerint a tritikále állománya kielégítően fejlődött, fitotoxicitásra utaló jeleket március, május, sőt július elején sem mutatott. Kivételt ez alól csupán a nagyobb Se-terheléses kezelésben lehetett igazolni. Itt az aratáskori szalmatermés 1,2 t/ha, a szemtermés 0,9 t/ha mennyiséggel csökkent. Mivel a szelén mobilis formában maradt a talajban és a mélyebb rétegekbe mosódott, a toxicitás a késői érési stádiumban jelentkezett, amikor a gyökerek a mélyebb talajrétegekkel is érintkezhettek. Eredményeinket a 2. táblázatban foglaltuk össze.

A kezelések hatását az aratáskori szem és szalma elemösszetételére a 3. táblázatban tanulmányozhatjuk. Amint az adatokból látható, az As-, Cr- és Ba-koncentráció a szemben még a leginkább szennyezett kezelésben sem éri el az $1 \mathrm{mg} / \mathrm{kg}$ értéket. Viszonylag gátolt a $\mathrm{Ni}, \mathrm{Ba}, \mathrm{Sr}$ és $\mathrm{Cu}$ elemek beépülése is a magtermésbe.

\section{2. táblázat}

Fitotoxikus kezelések hatása a tritikáléra 2003-ban

(Mészlepedékes csernozjom talaj, Nagyhörcsök)

\begin{tabular}{|c|c|c|c|c|c|c|}
\hline \multirow{2}{*}{$\begin{array}{l}\text { (1) } \\
\text { Elem } \\
\text { jele }\end{array}$} & \multicolumn{4}{|c|}{$\begin{array}{c}\text { (2) } \\
\text { Terhelés } 1991 \text { tavaszán, } \mathrm{kg} / \mathrm{ha}\end{array}$} & \multirow{2}{*}{$\begin{array}{l}(3) \\
\mathrm{SzD}_{5 \%}\end{array}$} & \multirow[t]{2}{*}{ Átlag } \\
\hline & 0 & 90 & 270 & 810 & & \\
\hline \multicolumn{7}{|c|}{ A. Bonitálás 2003. március 26-án } \\
\hline As & 4,5 & 4,5 & 5,0 & 4,5 & 1,0 & 4,6 \\
\hline Se & 4,5 & 4,5 & 4,5 & 4,5 & 1,0 & 4,5 \\
\hline \multicolumn{7}{|c|}{ B. Bonitálás 2003. május 19-én } \\
\hline As & 4,0 & 5,0 & 5,0 & 5,0 & 1,1 & 4,8 \\
\hline $\mathrm{Se}$ & 5,0 & 5,0 & 5,0 & 5,0 & 1,1 & 5,0 \\
\hline \multicolumn{7}{|c|}{ C. Bonitálás 2003. július 3-án } \\
\hline As & 4,5 & 4,5 & 4,5 & 3,5 & 1,2 & 4,2 \\
\hline $\mathrm{Se}$ & 5,0 & 4,5 & 4,5 & 3,5 & 1,2 & 4,4 \\
\hline \multicolumn{7}{|c|}{ D. Szalmatermés 2003. július 3-án, t/ha } \\
\hline As & 5,4 & 5,4 & 5,2 & 4,4 & 1,0 & 5,1 \\
\hline $\mathrm{Se}$ & 5,8 & 5,1 & 5,0 & 4,6 & 1,0 & 5,1 \\
\hline \multicolumn{7}{|c|}{ E. Szemtermés 2003. július 3-án, t/ha } \\
\hline As & 3,9 & 4,2 & 3,7 & 3,2 & 0,8 & 3,8 \\
\hline $\mathrm{Se}$ & 4,7 & 4,7 & 4,3 & 3,8 & 0,8 & 4,4 \\
\hline \multicolumn{7}{|c|}{ F. Légszáraz föld feletti hozam 2003. július 3-án, t/ha } \\
\hline As & 9,3 & 9,6 & 8,9 & 7,7 & 1,6 & 8,9 \\
\hline $\mathrm{Se}$ & 10,6 & 9,8 & 9,3 & 8,4 & 1,6 & 9,5 \\
\hline
\end{tabular}

Bonitálás: 1,0= igen gyengén fejlett; 5,0=igen jól fejlett állomány 
3. táblázat

Kezelések hatása a tritikále elemösszetételére aratáskor (2003. július 3-án)

(Mészlepedékes csernozjom talaj, Nagyhörcsök)

\begin{tabular}{|c|c|c|c|c|c|c|}
\hline \multirow{2}{*}{$\begin{array}{l}\text { (1) } \\
\text { Elem } \\
\text { jele }\end{array}$} & \multicolumn{4}{|c|}{$\begin{array}{c}\text { (2) } \\
\text { Terhelés } 1991 \text { tavaszán, } \mathrm{kg} / \mathrm{ha}\end{array}$} & \multirow{2}{*}{$\begin{array}{c}(3) \\
\mathrm{SzD}_{5 \%}\end{array}$} & \multirow[t]{2}{*}{ Átlag } \\
\hline & 0 & 90 & 270 & 810 & & \\
\hline \multicolumn{7}{|c|}{ A. A légszáraz szemben, $\mathrm{mg} / \mathrm{kg}$} \\
\hline As & 0,02 & 0,06 & 0,07 & 0,14 & 0,11 & 0,07 \\
\hline $\mathrm{Cd}$ & 0,05 & 2,25 & 2,96 & 4,21 & 2,11 & 2,37 \\
\hline $\mathrm{Cr}$ & 0,11 & 0,14 & 0,15 & 0,19 & 0,04 & 0,15 \\
\hline $\mathrm{Ni}$ & 0,20 & 1,04 & 1,28 & 1,70 & 0,48 & 1,06 \\
\hline $\mathrm{Ba}$ & 0,40 & 0,62 & 0,64 & 0,92 & 0,26 & 0,64 \\
\hline $\mathrm{Sr}$ & 1,40 & 2,06 & 2,36 & 3,70 & 0,52 & 2,38 \\
\hline $\mathrm{Cu}$ & 4,00 & 5,16 & 5,65 & 6,28 & 1,18 & 5,27 \\
\hline $\mathrm{Zn}$ & 12,2 & 48,9 & 55,9 & 68,7 & 29,9 & 46,4 \\
\hline Mo & 0,2 & 21,9 & 28,8 & 46,4 & 20,0 & 24,4 \\
\hline $\mathrm{Se}$ & 0,2 & 84,0 & 194,0 & 236,5 & 28,3 & 128,8 \\
\hline \multicolumn{7}{|c|}{ B. A légszáraz szalmában, $\mathrm{mg} / \mathrm{kg}$} \\
\hline As & $<\mathrm{KH}$ & 0,87 & 1,54 & 3,54 & 0,34 & 1,49 \\
\hline $\mathrm{Cd}$ & 0,10 & 2,18 & 5,08 & 7,46 & 1,50 & 3,70 \\
\hline $\mathrm{Cr}$ & 0,10 & 0,26 & 0,65 & 1,14 & 0,20 & 0,54 \\
\hline $\mathrm{Ni}$ & 0,07 & 0,37 & 0,40 & 0,47 & 0,22 & 0,33 \\
\hline $\mathrm{Cu}$ & 1,80 & 2,56 & 3,57 & 3,84 & 0,59 & 2,94 \\
\hline $\mathrm{Se}$ & 0,1 & 83,6 & 202,0 & 254,5 & 74,4 & 135,0 \\
\hline Mo & 0,2 & 68,8 & 111,4 & 220,0 & 51,4 & 100,0 \\
\hline $\mathrm{Zn}$ & 3,8 & 12,8 & 21,8 & 36,3 & 4,3 & 18,7 \\
\hline $\mathrm{Ba}$ & 10,0 & 17,3 & 17,4 & 26,7 & 7,3 & 17,8 \\
\hline $\mathrm{Sr}$ & 14,8 & 22,9 & 25,8 & 47,6 & 8,8 & 27,8 \\
\hline
\end{tabular}

Megjegyzés: Egyéb elemek átlagosan a szemben: N 2,22\%; K 0,57\%; P 0,39\%; S 0,16\%; Mg 0,12\%; Ca 349; Mn 34; Fe 33; Na 7; B 0,2 mg/kg, Egyéb elemek átlagosan a szalmában: K 1,40\%; N 0,88\%; Ca 0,38\%; S 0,16\%; Mg 0,11\%; P 702; Mn 82; Fe 59; Al 47; Na 13; B 4 $\mathrm{mg} / \mathrm{kg}$

Mindez sajnos nem mondható el a kadmiumról. Ez a veszélyes szennyező csaknem két nagyságrenddel dúsult és állati/humán fogyasztásra egyaránt alkalmatlan terméseket eredményezett. A Zn-terhelés nyomán megengedett $50 \mathrm{mg} \mathrm{Zn/kg} \mathrm{határérték}$ feletti koncentráció alakult ki. A kontrollhoz viszonyítva a molibdén mintegy 500szoros, míg a szelén 5000-szeres akkumulációt mutatott a maximális Mo-, ill. Seterheléses parcellákon, toxikus növényi termékeket eredményezve.

A vizsgált elemek közül a $\mathrm{Zn}, \mathrm{Cu}$ és Ni föként a szemben dúsult, míg az összes többi mikroelem döntően a melléktermés szárban. Az arzén pl. átlagosan 20-szoros koncentrációt jelez a szárban, a generatív szemhez képest. A Sr esetén a szár mintegy 10-szer, a Ba esetén közel 30-szor gazdagabb a szemnél, míg a Mo átlagosan csupán 4-szer vagy 5-ször. A N, K, P, S és Mg 2,22, 0,57, 0,39, 0,16 és 0,12\%-ot 
tett ki a szemben. Ugyanitt a Ca, Mn, Fe, $\mathrm{Na}$ és B 349, 34, 33, 7 és $0,2 \mathrm{mg} / \mathrm{kg}$ volt átlagosan. A szalmában a $\mathrm{K}, \mathrm{N}, \mathrm{Ca}, \mathrm{S}$ és $\mathrm{Mg} 1,40,0,88,0,38,0,16$ és $0,11 \%$-ot ért el, míg a P, Mn, Fe, Al, Na és B 702, 82, 59, 47, 13 és 4 mg/kg-ot a szárazanyagban.

\section{4. táblázat}

Kezelések hatása a tritikále elemfelvételére aratáskor 2003. július 3-án (Mészlepedékes csernozjom talaj, Nagyhörcsök)

\begin{tabular}{|c|c|c|c|c|c|c|}
\hline \multirow{2}{*}{$\begin{array}{l}\text { (1) } \\
\text { Elem } \\
\text { jele }\end{array}$} & \multicolumn{4}{|c|}{$\begin{array}{l}\text { (2) } \\
\text { Terhelés } 1991 \text { tavaszán, kg/ha }\end{array}$} & \multirow{2}{*}{$\begin{array}{c}(3) \\
\mathrm{SzD}_{5 \%}\end{array}$} & \multirow[t]{2}{*}{ Átlag } \\
\hline & 0 & 90 & 270 & 810 & & \\
\hline \multicolumn{7}{|c|}{ A. Szemtermésben, $\mathrm{g} / \mathrm{ha}$} \\
\hline As & 0,08 & 0,25 & 0,26 & 0,45 & 0,22 & 0,26 \\
\hline $\mathrm{Cr}$ & 0,46 & 0,59 & 0,63 & 0,80 & 0,10 & 0,62 \\
\hline $\mathrm{Ba}$ & 1,68 & 2,60 & 2,69 & 3,86 & 1,12 & 2,71 \\
\hline $\mathrm{Ni}$ & 0,84 & 4,37 & 5,38 & 7,14 & 2,46 & 4,43 \\
\hline $\mathrm{Cd}$ & 0,21 & 9,45 & 12,40 & 17,68 & 8,11 & 9,94 \\
\hline $\mathrm{Sr}$ & 6 & 9 & 10 & 16 & 4 & 10 \\
\hline $\mathrm{Cu}$ & 17 & 22 & 24 & 26 & 6 & 22 \\
\hline $\mathrm{Se}$ & 1 & 40 & 83 & 90 & 37 & 53 \\
\hline Mo & 1 & 92 & 121 & 195 & 84 & 102 \\
\hline $\mathrm{Zn}$ & 51 & 205 & 234 & 289 & 88 & 195 \\
\hline \multicolumn{7}{|c|}{ B. Szalmatermésben, g/ha } \\
\hline $\mathrm{Ni}$ & 0,4 & 2,1 & 2,2 & 2,6 & 0,8 & 1,8 \\
\hline $\mathrm{Cr}$ & 0,6 & 1,5 & 3,6 & 6,4 & 1,4 & 3,0 \\
\hline As & 0,1 & 4,7 & 8,0 & 15,6 & 3,4 & 7,1 \\
\hline $\mathrm{Cd}$ & 0,6 & 12,2 & 28,4 & 41,8 & 11,6 & 20,8 \\
\hline $\mathrm{Cu}$ & 10,1 & 14,3 & 20,0 & 21,5 & 4,4 & 16,5 \\
\hline $\mathrm{Zn}$ & 21 & 72 & 122 & 203 & 36 & 104 \\
\hline $\mathrm{Ba}$ & 56 & 97 & 97 & 150 & 48 & 100 \\
\hline $\mathrm{Sr}$ & 83 & 128 & 144 & 267 & 53 & 156 \\
\hline Mo & 1 & 385 & 624 & 1232 & 282 & 560 \\
\hline $\mathrm{Se}$ & 1 & 426 & 1010 & 1171 & 333 & 652 \\
\hline \multicolumn{7}{|c|}{ C. Együtt, g/ha } \\
\hline As & 0,2 & 5,0 & 8,3 & 16,0 & 3,7 & 7,4 \\
\hline $\mathrm{Cr}$ & 1,1 & 2,1 & 4,2 & 7,2 & 1,7 & 3,6 \\
\hline $\mathrm{Ni}$ & 1,2 & 6,5 & 7,6 & 9,7 & 3,0 & 6,2 \\
\hline $\mathrm{Cd}$ & 0,8 & 21,6 & 40,8 & 59,5 & 19,4 & 30,7 \\
\hline $\mathrm{Cu}$ & 26,9 & 36,0 & 43,7 & 47,9 & 9,7 & 38,7 \\
\hline $\mathrm{Ba}$ & 58 & 100 & 100 & 154 & 49 & 103 \\
\hline $\mathrm{Sr}$ & 89 & 137 & 154 & 283 & 58 & 166 \\
\hline $\mathrm{Zn}$ & 72 & 277 & 356 & 492 & 122 & 299 \\
\hline Mo & 2 & 477 & 745 & 1427 & 352 & 662 \\
\hline $\mathrm{Se}$ & 2 & 466 & 1093 & 1261 & 360 & 705 \\
\hline
\end{tabular}


A 4. táblázat adatai tájékoztatnak a föld feletti terméssel felvett mikroelemek mennyiségeiről. A maximális felvételeket tekintve (az erősen szennyezett talajon és a szennyezést követő 13. év után) a hektáronkénti elemakkumuláció a következöképpen alakult: Cr 7 g, Ni 10 g, As 16 g, Cu 48 g, Cd 60 g, Ba 154 g, Sr 283 g, Zn $492 \mathrm{~g}$, Se $1261 \mathrm{~g}$ és Mo $1427 \mathrm{~g}$. A fitoremediáció esélyeit latolgatva hasonló körülmények között (a maximális $810 \mathrm{~kg}$ /ha szennyezés eltávolításához) a molibdén esetében kereken 568, a szelén esetében 642, a cink esetében 1646, míg a kadmium esetében 13500 évre volna szükség a talaj teljes tisztulásához. Az erősen szennyezett talajok tisztításához tehát a fitoremediáció a tritikále tesztnövénnyel vizsgálva nem nyújthat reális alternatívát. Annak ellenére, hogy e növény kiválóan elviselheti a monokultúrás termesztést.

Az 5. táblázatban iránymutató jelleggel összeállítottuk a tritikále termésébe szennyezetlen talajon beépült makro- és mikroelemek mennyiségeit, ill. megbecsültük az $1 \mathrm{t}$ magtermés és a hozzá tartozó melléktermés ún. fajlagos elemtartalmát a szaktanácsadás számára. Adataink szerint a tervezett $1 \mathrm{t}$ föterméshez tartozó fajlagos elemigény az alábbi lehet hasonló körülmények között: $30-34 \mathrm{~kg} \mathrm{~N}, 24-25 \mathrm{~kg}$ $\mathrm{K}\left(28-30 \mathrm{~kg} \mathrm{~K}_{2} \mathrm{O}\right), 4-5 \mathrm{~kg} \mathrm{P}\left(9-12 \mathrm{~kg} \mathrm{P}_{2} \mathrm{O}_{5}\right), 5-6 \mathrm{~kg} \mathrm{Ca}, 3-4 \mathrm{~kg} \mathrm{~S}, 2-3 \mathrm{~kg} \mathrm{Mg}$.

\section{5. táblázat}

A tritikále föld feletti termésébe épült elemek átlagos és fajlagos mennyiségei szennyezetlen talajon aratáskor 2003. július 3-án (Mészlepedékes csernozjom talaj, Nagyhörcsök)

\begin{tabular}{|ll|c|c|c|c|}
\hline \multicolumn{2}{|c|}{$\begin{array}{c}\text { Elem jele és } \\
\text { mértékegysége }\end{array}$} & $\begin{array}{c}(2) \\
\text { Szem- } \\
\text { termés } \\
4,2 \mathrm{t} / \mathrm{ha}\end{array}$ & $\begin{array}{c}(3) \\
\text { Szalma- } \\
\text { termés } \\
5,6 \mathrm{t} / \mathrm{ha}\end{array}$ & $\begin{array}{c}(4) \\
\text { Osszes } \\
\text { termés } \\
9,8 \mathrm{t} / \mathrm{ha}\end{array}$ & $\begin{array}{c}(5) \\
\begin{array}{c}\text { Fajlagos } \\
\text { elem- } \\
\text { tartalom* }\end{array}\end{array}$ \\
\hline $\mathrm{N}$ & $\mathrm{kg} / \mathrm{ha}$ & 93,2 & 49,3 & 142 & 33,8 \\
$\mathrm{~K}$ & $\mathrm{~kg} / \mathrm{ha}$ & 23,9 & 78,4 & 102 & 24,3 \\
$\mathrm{P}$ & $\mathrm{kg} / \mathrm{ha}$ & 16,4 & 3,9 & 20 & 4,8 \\
$\mathrm{~S}$ & $\mathrm{~kg} / \mathrm{ha}$ & 6,7 & 9,0 & 16 & 3,8 \\
$\mathrm{Mg}$ & $\mathrm{kg} / \mathrm{ha}$ & 5,0 & 6,2 & 11 & 2,6 \\
$\mathrm{Ca}$ & $\mathrm{kg} / \mathrm{ha}$ & 1,5 & 21,3 & 23 & 5,5 \\
$\mathrm{Mn}$ & $\mathrm{g} / \mathrm{ha}$ & 143 & 459 & 602 & 143 \\
$\mathrm{Fe}$ & $\mathrm{g} / \mathrm{ha}$ & 139 & 330 & 469 & 112 \\
$\mathrm{Al}$ & $\mathrm{g} / \mathrm{ha}$ & 1 & 263 & 264 & 63 \\
$\mathrm{Zn}$ & $\mathrm{g} / \mathrm{ha}$ & 51 & 4 & 55 & 13 \\
$\mathrm{Na}$ & $\mathrm{g} / \mathrm{ha}$ & 29 & 73 & 102 & 24 \\
$\mathrm{Cu}$ & $\mathrm{g} / \mathrm{ha}$ & 17 & 2 & 19 & 5 \\
$\mathrm{Sr}$ & $\mathrm{g} / \mathrm{ha}$ & 6 & 15 & 21 & 5 \\
$\mathrm{Ba}$ & $\mathrm{g} / \mathrm{ha}$ & 2 & 10 & 12 & 3 \\
$\mathrm{Ni}$ & $\mathrm{g} / \mathrm{ha}$ & 0,8 & 0,1 & 0,9 & 0,2 \\
$\mathrm{Cr}$ & $\mathrm{g} / \mathrm{ha}$ & 0,5 & 0,1 & 0,6 & 0,1 \\
$\mathrm{Mo}$ & $\mathrm{g} / \mathrm{ha}$ & 1,0 & 0,2 & 1,2 & 0,3 \\
$\mathrm{Se}$ & $\mathrm{g} / \mathrm{ha}$ & 1,0 & 0,1 & 1,1 & 0,3 \\
\hline
\end{tabular}

*Fajlagos, azaz 1 t szem- + a hozzá tartozó szalmatermés elemtartalma. Az As-, Hg-, Pb-, Co- és Cd-tartalom általában $1 \mathrm{~g} /$ ha méréshatár alatt maradt 
A zsizsikes magvak mennyisége a kontrollparcellákon 16\% körülinek adódott. A maximális Zn-terhelés nyomán, ahol a Zn-koncentráció kereken $69 \mathrm{mg} / \mathrm{kg}$ volt a légszáraz magban, a fertözés igazolhatóan a felére mérséklődött. Ugyanitt már enyhén, de igazolhatóan csökkent a csíranövénykék magassága és tömege is. A cink a csíranövények hajtásában halmozódott fel nagyobb koncentrációban, mint eredetileg a magban volt (6. táblázat).

A Mo-terhelés a zsizsikes magvak arányát érdemben nem befolyásolta. Az elvetett mag és a csíranövény hajtásának Mo-koncentrációja lényegesen nem tért el egymástól. A csíranövények magassága, hajtásának és gyökerének tömege viszont a nagyobb Mo-szennyezés nyomán igazolhatóan visszaesett. Úgy tünik a Se-dús magvakat a zsizsik elkerülte, a fertőzés alig jelentkezett. A csíranövények magasságában, a hajtás és a gyökér tömegében igazolható depresszió csak a maximális terhelésnél következett be. A hajtás Se-koncentrációja mintegy 30\%-kal haladta meg a mag Se-készletét (6. táblázat).

\section{6. táblázat}

A Zn-, Mo- és Se-kezelések hatása a tritikáléra 2003-ban (Mészlepedékes csernozjom talaj, Nagyhörcsök)

\begin{tabular}{|c|c|c|c|c|c|c|}
\hline \multirow{2}{*}{$\begin{array}{l}\text { (1) } \\
\text { Megfigyelt, ill. vizsgált } \\
\text { jellemzők }\end{array}$} & \multicolumn{4}{|c|}{$\begin{array}{c}\text { (2) } \\
\text { Terhelés } 1991 \text { tavaszán, kg/ha }\end{array}$} & \multirow[t]{2}{*}{$\begin{array}{l}(3) \\
\mathrm{SzD}_{5 \%}\end{array}$} & \multirow[t]{2}{*}{ Átlag } \\
\hline & 0 & 90 & 270 & 810 & & \\
\hline \multicolumn{7}{|c|}{ A. Zn-terhelés hatására } \\
\hline a) Zsizsikes magvak \%-a & 16,4 & 15,1 & 15,1 & 6,7 & 4,2 & 13,3 \\
\hline $\begin{array}{l}\text { b) } \mathrm{Zn}, \mathrm{mg} / \mathrm{kg} \text { a magban } \\
\text { c) A csíranövény: }\end{array}$ & 12,2 & 48,9 & 55,9 & 68,7 & 29,9 & 46,4 \\
\hline d) magassága, cm (hajtás) & 7,9 & 8,2 & 7,8 & 6,6 & 1,1 & 7,6 \\
\hline e) hajtás sz.a. mg/növény & 5,2 & 5,4 & 5,2 & 4,1 & 0,8 & 5,0 \\
\hline f) gyökér sz.a. mg/növény & 8,6 & 8,7 & 8,4 & 6,9 & 1,2 & 8,1 \\
\hline g) Zn, mg/kg a hajtásban & 44 & 72 & 73 & 82 & 10 & 72 \\
\hline \multicolumn{7}{|c|}{ B. Mo-terhelés hatására } \\
\hline a) Zsizsikes magvak \%-a & 16,3 & 22,3 & 23,3 & 20,1 & 6,2 & 20,5 \\
\hline $\begin{array}{l}\text { b) Mo, mg/kg a magban } \\
\text { c) A csíranövény: }\end{array}$ & 0,2 & 21,9 & 28,8 & 46,4 & 20,0 & 24,4 \\
\hline d) magassága, cm (hajtás) & 8,3 & 7,4 & 7,2 & 6,9 & 0,9 & 7,4 \\
\hline e) hajtás sz.a. mg/növény & 5,5 & 4,5 & 4,1 & 3,8 & 0,9 & 4,5 \\
\hline f) gyökér sz.a. mg/növény & 7,9 & 6,5 & 6,0 & 5,7 & 0,7 & 6,5 \\
\hline g) Mo, mg/kg a hajtásban & 0,6 & 22 & 31 & 42 & 11 & 28 \\
\hline \multicolumn{7}{|c|}{ C. Se-terhelés hatására } \\
\hline a) Zsizsikes magvak \%-a & 15,9 & 5,7 & 1,9 & 1,0 & 4,2 & 6,1 \\
\hline $\begin{array}{l}\text { b) } \mathrm{Se}, \mathrm{mg} / \mathrm{kg} \text { a magban } \\
\text { c) A csíranövény: }\end{array}$ & 0,2 & 84 & 194 & 236 & 28 & 129 \\
\hline d) magassága, cm (hajtás) & 8,0 & 10,4 & 9,7 & 8,1 & 1,4 & 9,0 \\
\hline e) hajtás sz.a. mg/növény & 6,7 & 8,9 & 7,1 & 6,9 & 1,4 & 7,4 \\
\hline f) gyökér sz.a. mg/növény & 10,1 & 12,1 & 10,8 & 10,5 & 1,7 & 10,9 \\
\hline g) Se, mg/kg a hajtásban & 0,4 & 117 & 247 & 286 & 36 & 173 \\
\hline
\end{tabular}

Megjegyzés: a kezelések 40 növényegyedet/magot tartalmaztak; 4 ismétlés, $n=160$ 


\section{Összefoglalás}

Löszön képződött vályog mechanikai összetételü karbonátos csernozjom talajon, az MTA Talajtani és Agrokémiai Kutatóintézet Nagyhörcsöki Kísérleti Telepén szabadföldi kisparcellás mikroelem-terhelési kísérletet állítottunk be 1991 tavaszán. A termőhely talajának szántott rétege mintegy $5 \% \mathrm{CaCO}_{3}$-ot és $3 \%$ humuszt tartalmazott, oldható tápelemekkel való ellátottsága az alábbi volt: Ca és $\mathrm{Mn}$ igen jó, $\mathrm{Mg}$ és $\mathrm{Cu}$ kielégítö, $\mathrm{N}$ és $\mathrm{K}$ közepes, $\mathrm{P}$ és $\mathrm{Zn}$ gyenge. A talajvíz $15 \mathrm{~m}$ mélyen helyezkedik el, a terület vízmérlege negatív, aszályra hajló. A 13 vizsgált mikroelem sóit 44 szinten alkalmaztuk 1991 tavaszán, a kukorica vetése előtt. A 13×4 = 52 kezelést 2 ismétlésben állítottuk be összesen 104 parcellán split-plot elrendezésben. A kísérlet terhelési szintjei $0,90,270$, ill. $810 \mathrm{~kg} / \mathrm{ha}$ mennyiséget jelentettek elemenként $\mathrm{AlCl}_{3}, \mathrm{As}_{2} \mathrm{O}_{3} / \mathrm{NaAsO}_{2}, \mathrm{BaCl}_{2}, \mathrm{CdSO}_{4}, \mathrm{~K}_{2} \mathrm{CrO}_{4}, \mathrm{CuSO}_{4}, \mathrm{HgCl}_{2},\left(\mathrm{NH}_{4}\right)_{6} \mathrm{Mo}_{7} \mathrm{O}_{24}$, $\mathrm{NiSO}_{4}, \mathrm{~Pb}\left(\mathrm{NO}_{3}\right)_{2}, \mathrm{Na}_{2} \mathrm{SeO}_{3}, \mathrm{SrSO}_{4}$ és $\mathrm{ZnSO}_{4}$ formájában. A kísérlet 13. évében tritikálét termesztettünk.

A kísérleti eredmények alapján levonható főbb tanulságok a következők:

- A viszonylag száraz évben mérsékelt szem- (4-5 t/ha), ill. szalmaterméseket (5-6 t/ha) kaptunk. Fitotoxicitást, igazolható terméscsökkenést aratás idején a maximális As- és Se-terhelés okozott, melynek mértéke átlagosan 20\% körül ingadozott a kontrollhoz viszonyítva.

- Az As-, Cr- és Ba-koncentráció még az adott elem maximális $(810 \mathrm{~kg} / \mathrm{ha})$ terhelése esetén sem érte el az $1 \mathrm{mg} / \mathrm{kg}$ értéket a tritikále szemtermésében. Viszonylag gátolt a $\mathrm{Ni}, \mathrm{Ba}, \mathrm{Sr}$ és $\mathrm{Cu}$ elemek beépülése is a magtermésbe. A Cd csaknem két nagyságrenddel dúsult a kadmiummal erősen szennyezett talajon és humán-, valamint állati fogyasztásra egyaránt alkalmatlan termést eredményezett. A megengedett $50 \mathrm{mg} \mathrm{Zn/kg} \mathrm{határérték} \mathrm{feletti} \mathrm{koncentrációt} \mathrm{regisztráltunk} \mathrm{a} \mathrm{Zn-terhelés} \mathrm{nyo-}$ mán. A maximális Mo-, ill. Se-terhelés esetében a kontrollhoz viszonyítva a Mo mintegy 500-szoros, míg a Se 5000-szeres akkumulációt mutatott a szemben, toxikus növényi terméket produkálva.

- A vizsgált elemek közül a $\mathrm{Zn}, \mathrm{Cu}$ és Ni föként a szemben dúsult, míg az öszszes többi elem döntően a vegetatív melléktermésben. A szalma pl. molibdénban átlagosan 4-5-ször, stronciumban 10-szer, arzénban 20-szor és báriumban 30-szor gazdagabb volt, mint a szem. Takarmányként állati fogyasztásra alkalmatlannak minősült a szalma a Cd-, Se- és Mo-kezelések mindegyikében, valamint a maximális As-terhelés esetén.

- A tritikále föld feletti (szem+szalma) termésébe maximálisan és kereken $7 \mathrm{~g}$ Cr, 10 g Ni, 16 g As, 48 g Cu, 60 g Cd, 154 g Ba, 283 g Sr, 492 g Zn, 1261 g Se és $1427 \mathrm{~g}$ Mo épült be hektáronként. A maximális $810 \mathrm{~kg} / \mathrm{ha}$ talajszennyezés eltávolításához hasonló körülmények között (fitoremediáció) tehát a Mo esetében kereken 568, a Zn esetében 1646, míg a Cd esetében pl. 13500 évre volna szükség. Az erösen szennyezett talajok remediációjához a tritikále, mint tesztnövény nem nyújt reális alternatívát annak ellenére, hogy kiválóan elviseli a monokultúrát.

- A tritikále $1 \mathrm{t}$ főtermésének + a hozzá tartozó melléktermés elemigénye kísérleti viszonyaink között az alábbinak adódott: $30-34 \mathrm{~kg} \mathrm{~N}, 24-25 \mathrm{~kg} \mathrm{~K}(28-30 \mathrm{~kg}$ $\left.\mathrm{K}_{2} \mathrm{O}\right), 4-5 \mathrm{~kg} \mathrm{P}\left(9-12 \mathrm{~kg} \mathrm{P}_{2} \mathrm{O}_{5}\right), 5-6 \mathrm{~kg} \mathrm{Ca}, 3-4 \mathrm{~kg} \mathrm{~S}, 2-3 \mathrm{~kg} \mathrm{Mg}$. 
- A búza zsizsikkel (Sitophilus granarius) fertőzött magtermése a kontrollparcellákon $16 \%$ körüli volt. A Mo-kezelés nem befolyásolta, a maximális $\mathrm{Zn}$-terhelés a fertőzést felére mérsékelte, míg a Se-dús magvakat a fertőzés elkerülte. Az elvetett magvak és a csíranövények hajtásának Mo-koncentrációja közelálló volt, míg a hajtások 20-30\%-kal nagyobb Zn- és Se-tartalmakat mutattak. A csíranövénykék magassága, hajtás- és gyökértömege igazolhatóan mérséklődött a nagyobb (maximális) Zn-, Mo- és Se-terhelés nyomán. A vizsgált mikroelemek a magból a hajtásba vándoroltak (remobilizáció).

Kulcsszavak: tritikále, mikroelem-terhelés, fitoremediáció, tartamkísérlet

\section{Irodalom}

KÁDÁR I., KASTORI R. \& BERNÁTH J., 2003. Mikroelem-terhelés hatása a mákra karbonátos csernozjom talajon. Agrokémia és Talajtan. 52.347-362.

KÁDÁR I., NÉMETH T. \& SZEMES I., 1999. Tritikále trágyareakciója a nyírlugosi tartamkísérletben. Növénytermelés. 48. 647-661.

KÁDÁR I., RADICS L. \& BANA K.-NÉ, 2000. Mikroelem-terhelés hatása a kukoricára karbonátos csernozjom talajon. Agrokémia és Talajtan. 49. 181-204.

KÁDÁR I. \& SzEMES I., 1994. A nyírlugosi tartamkísérlet 30 éve. MTA Talajtani és Agrokémiai Kutató Intézete. Budapest.

LÁsZTiTY B., 1984. Az NPK-műtrágyázás hatása az őszi rozs és a tritikále szemtermésének néhány beltartalmi jellemzöjére. Agrokémia és Talajtan. 33. 391-402.

LÁSZTITY B., 1986. Néhány elem koncentrációjának változása az őszi rozsban és tritikáléban a tenyészidő folyamán. Agrokémia és Talajtan. 35. 85-94.

LÁsZTITY B., 1987-1988. A mütrágyázás hatása a tritikále szárazanyag felhalmozására és tápelemtartalmára. Agrokémia és Talajtan. 36-37. 191-208.

LÁsZTiTY B. \& BiczóK GY., 1987-1988. A mütrágyázás hatása a tritikále tápelemfelvételének dinamikájára. Agrokémia és Talajtan. 36-37. 177-190.

SzÜCS L., 1965. A mészlepedékes csernozjomok osztályozásának továbbfejlesztése és alkalmazása. Agrokémia és Talajtan. 14. 153-172.

VoHRA, P. et al., 1991. Triticale, an alternative cereal grain in broiler starter diets. California Agriculture. 45. 34-37.

Érkezett: 2005. szeptember 7. 


\title{
Effect of Microelement Loads on the Yield and Nutrient Uptake of Triticale on Calcareous Chernozem Soil
}

\author{
I. KÁDÁR and R. KASTORI \\ Research Institute for Soil Science and Agricultural Chemistry (RISSAC) of the Hungarian Acad- \\ emy of Sciences, Budapest and Research Institute for Field and Vegetable Crops, Faculty of \\ Agriculture, University of Novi Sad, Novi Sad
}

\section{Summary}

A small-plot field experiment designed to test microelement loads was set up in spring 1991 on a calcareous chernozem soil with a loam texture, formed on loess, at the Nagyhörcsök Experimental Station of RISSAC. The ploughed layer contained around $5 \% \mathrm{CaCO}_{3}$ and $3 \%$ humus, and the nutrient supply level was very good for $\mathrm{Ca}$ and $\mathrm{Mn}$, satisfactory for $\mathrm{Mg}$ and $\mathrm{Cu}$, moderate for $\mathrm{N}$ and $\mathrm{K}$, and poor for $\mathrm{P}$ and $\mathrm{Zn}$. The groundwater was located at a depth of $15 \mathrm{~m}$, and the territory had a negative water balance and was prone to drought. Salts of the 13 microelements tested were each applied at four levels in spring 1991, prior to the sowing of maize. The $13 \times 4=52$ treatments were carried out in two replications, giving a total of 104 plots in a split-plot design. The pollution levels established in the experiment were $0,90,270$ and $810 \mathrm{~kg} / \mathrm{ha}$ for each element, and were applied in the form of $\mathrm{AlCl}_{3}, \mathrm{As}_{2} \mathrm{O}_{3} / \mathrm{NaAsO}_{2}, \mathrm{BaCl}_{2}, \mathrm{CdSO}_{4}, \mathrm{~K}_{2} \mathrm{CrO}_{4}$, $\mathrm{CuSO}_{4}, \mathrm{HgCl}_{2},\left(\mathrm{NH}_{4}\right)_{6} \mathrm{Mo}_{7} \mathrm{O}_{24}, \mathrm{NiSO}_{4}, \mathrm{~Pb}\left(\mathrm{NO}_{3}\right)_{2}, \mathrm{Na}_{2} \mathrm{SeO}_{3}, \mathrm{SrSO}_{4}$ and $\mathrm{ZnSO}_{4}$. In the $13^{\text {th }}$ year of the experiment triticale (cv. Kitaro) was sown on 1 October 2002 at a depth of 4-6 cm with 55-60 germs per metre, i.e. $200-220 \mathrm{~kg} \mathrm{seed} / \mathrm{ha}$.

The main conclusions that could be drawn from the results were as follows:

- In this relatively dry year, moderate grain (4-5 t/ha) and straw (5-6 t/ha) yields were obtained. Phytotoxicity and significant yield losses at harvest, averaging around $20 \%$ compared with the control, were caused by the maximum rates of As and Se.

- Even at the maximum ( $810 \mathrm{~kg} / \mathrm{ha})$ load with the given element, the $\mathrm{As}, \mathrm{Cr}$ and $\mathrm{Ba}$ concentrations in the grain yield of triticale did not reach the $1 \mathrm{mg} / \mathrm{kg}$ value. The incorporation of $\mathrm{Ni}, \mathrm{Ba}, \mathrm{Sr}$ and $\mathrm{Cu}$ into the grain yield was also relatively inhibited. On soil severely contaminated with cadmium, the $\mathrm{Cd}$ concentration increased by nearly two orders of magnitude, leading to grain unsuitable for either human or animal consumption. Zinc concentrations above the $50 \mathrm{mg} / \mathrm{kg}$ limit value were observed as the result of $\mathrm{Zn}$ load. As the result of maximum Mo and Se loads, the accumulation of Mo and Se reached 500 times and 5000 times the control level, respectively, leading to toxic plant products.

- Among the elements analysed, $\mathrm{Zn}, \mathrm{Cu}$ and $\mathrm{Ni}$ were concentrated primarily in the grain, while the others were mainly found in the vegetative by-products. For example, the straw contained 4-5 times as much Mo, 10 times as much Sr, 20 times as much As and 30 times as much $\mathrm{Ba}$ as the grain. The straw was classified as unsuitable for animal consumption in all the $\mathrm{Cd}$, Se and Mo treatments and in the case of the maximum As contamination.

- The maximum quantities of microelements incorporated into the aboveground organs (grain+straw) of triticale were approximately $7 \mathrm{~g} \mathrm{Cr}, 10 \mathrm{~g} \mathrm{Ni}, 16 \mathrm{~g} \mathrm{As}, 48 \mathrm{~g} \mathrm{Cu}, 60$ $\mathrm{g} \mathrm{Cd}, 154 \mathrm{~g} \mathrm{Ba}, 283 \mathrm{~g} \mathrm{Sr}, 492 \mathrm{~g} \mathrm{Zn}, 1261 \mathrm{~g}$ Se and $1427 \mathrm{~g}$ Mo per hectare. This means 
that to remove the maximum $810 \mathrm{~kg}$ /ha quantity of soil contamination by phytoremediation would require a total of 568 years in the case of Mo, 1646 years for $\mathrm{Zn}$ and 13500 years for $\mathrm{Cd}$. Triticale is thus not a viable alternative for the remediation of severely contaminated soils, despite the fact that it gives excellent results when grown in a monoculture.

- Under the given experimental conditions the element requirements of $1 \mathrm{t}$ main product + the corresponding by-products for triticale were found to be: $30-34 \mathrm{~kg} \mathrm{~N}, 24$ $25 \mathrm{~kg} \mathrm{~K}\left(28-30 \mathrm{~kg} \mathrm{~K}_{2} \mathrm{O}\right), 4-5 \mathrm{~kg} \mathrm{P}\left(9-12 \mathrm{~kg} \mathrm{P}_{2} \mathrm{O}_{5}\right), 5-6 \mathrm{~kg} \mathrm{Ca}, 3-4 \mathrm{~kg} \mathrm{~S}$ and 2-3 kg $\mathrm{Mg}$.

- The proportion of wheat grains infested with weevils (Sitophilus granarius) was around $16 \%$ in the control plots. This was not influenced by Mo treatment, while the maximum $\mathrm{Zn}$ load reduced the infestation to half and Se-rich seeds were free of weevils. The Mo concentration in sown seeds and seedling shoots was much the same, while the shoots exhibited $20-30 \%$ higher contents of $\mathrm{Zn}$ and Se. The height of the seedlings and their shoot and root mass were significantly smaller as the result of maximum levels of $\mathrm{Zn}$, Mo and Se. The microelements investigated migrated from the seed into the shoot (remobilization).

Table 1. Treatments and operations in the triticale experiment in 2003 (Calcareous chernozem soil, Nagyhörcsök). (1) Treatments and operations. (2) Year, month, day. (3) Notes.

Table 2. Effect of phytotoxic treatments on triticale in 2003 (Calcareous chernozem soil, Nagyhörcsök). (1) Element symbol. (2) Element load applied in spring 1991,

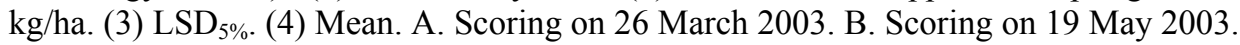
C. Scoring on 3 July 2003. D. Straw yield on 3 July 2003. E. Grain yield on 3 July 2003. F. Air-dry aboveground yield on 3 July 2003. Note: Scores: $1.0=$ very poorly developed stand; $5.0=$ very well developed stand.

Table 3. Effect of treatments on the element composition of triticale at harvest (on 3 July 2003) (Calcareous chernozem soil, Nagyhörcsök). (1)-(4): see Table 2. A. In airdry grains, $\mathrm{mg} / \mathrm{kg}$. B. In air-dry straw, $\mathrm{mg} / \mathrm{kg}$. Note: Average quantities of other elements in the grain and straw.

Table 4. Effect of treatments on the element uptake of triticale at harvest on 3 July 2003 (Calcareous chernozem soil, Nagyhörcsök). (1)-(4): see Table 2. A. In the grain yield, g/ha. B. In the straw yield, g/ha. C. Together, g/ha.

Table 5. Average and specific quantities of elements incorporated into the aboveground yield of triticale on untreated soil at harvest on 3 July 2003 (Calcareous chernozem soil, Nagyhörcsök). (1) Element symbol and units. (2) Grain yield, 4.2 t/ha. (3) Straw yield, $5.6 \mathrm{t} / \mathrm{ha}$. (4) Total yield, $9.8 \mathrm{t} / \mathrm{ha}$. (5) Specific element content*. Note: Specific element content, i.e. that of $1 \mathrm{t}$ grain + the corresponding straw yield. Contents of $\mathrm{As}, \mathrm{Hg}, \mathrm{Pb}, \mathrm{Co}$ and $\mathrm{Cd}$ were generally below the $1 \mathrm{~g} /$ ha detection limit.

Table 6. Effect of $\mathrm{Zn}$, Mo and Se treatments on triticale in 2003 (Calcareous chernozem soil, Nagyhörcsök). (1) Observed or analysed parameters. a) \% seeds infested with weevils; b) Zn, Mo and Se quantities, $\mathrm{mg} / \mathrm{kg}$, in the seed; c) Seedling; d) Height, cm (shoot); e) Shoot dry matter, mg/plant; f) Root dry matter, mg/plant; g) Zn, Mo and $\mathrm{Se}, \mathrm{mg} / \mathrm{kg}$ in the shoot. (2)-(4): see Table 2. Note: Treatments carried out on 40 plants or seeds; 4 replications; $n=160$. 